\title{
PEMETAAN KERAWANAN KRIMINALITAS DI WILAYAH HUKUM KEPOLISIAN RESORT (POLRES) KOTA PAYAKUMBUH TAHUN 2014
}

\author{
Afni Rizka Azwardi ${ }^{1}$, Paus Iskarni ${ }^{2}$, Endah Purwaningsih \\ Program Studi Pendidikan Geografi, \\ Fakultas Ilmu Sosial, Universitas Negeri Padang \\ Email: rizqia_azwardi@ymail.com
}

\begin{abstract}
Abstrak
Tujuan penelitian ini untuk: (1) Mengetahui jenis tindak kriminalitas dan persentase setiap jenis tindak kriminalitas yang terjadi di Wilayah Hukum Kepolisian Resort (POLRES) Kota Payakumbuh tahun 2014. (2) Memetakan kerawanan kriminalitas di Wilayah Hukum Kepolisian Resort (POLRES) Kota Payakumbuh tahun 2014.Jenis penelitian deskriptif kuantitatif .Teknik analisis data dilakukan dengan menggunakan metode analisis statistik dan teknik overlay pada peta.Hasil penelitian menemukan bahwa: (1) Jenis tindak kriminalitas meliputi jenis kriminal yaitu: Curas (pencurian dengan kekerasan) sebanyak 88 kasus. Curat (pencurian dengan pemberatan) sebanyak 242 kasus. Curanmor (pencurian sepeda bermotor) sebanyak 87 kasus. Anirat (penganiayaan berat) sebanyak 176 kasus dan Aniring (penganiayaan ringan) sebanyak 160 kasus. Persentase perbandingan antara berbagai jenis kejahatan atau tindak kriminalitas tertinggi sebesar 38,5\% untuk Curat di Kecamatan Lampasi Tigo Nagari dan yang paling rendah sebesar 6,1\% untuk Curanmor terjadi di Kecamatan Luhak. (2) Kerawanan kriminalitas tertinggi terjadi di Kecamatan Payakumbuh Barat sebesar 49 kali per satuan penduduk dan terendah di Kecamatan Lampasi Tigo Nagari sebesar 4 kali per satuan penduduk.
\end{abstract}

Kata Kunci: Kriminalitas, Peta, Kerawanan

\begin{abstract}
The purpose of this study to: (1) Determine the type of crime and the percentage of each type of crime that occurred in the jurisdiction of Police Resort (the police) of Payakumbuh in the year of 2014. (2) Mapping vulnerability crime in the jurisdiction of Police Resort (the police) Payakumbuh in the year of 2014. Type of study is descriptive quantitative research using secondary data. Analysis of data used statistical analysis methods and techniques overlay on the map. The study found that: (1) Type of crime examined included criminal types, namely: Curas (theft with violence) as many as 88 cases. Curat (theft by weighting) as many as 242 cases. Curanmor (motorized bicycle theft) as many as 87 cases. Anirat (severe persecution) of 176 cases and Aniring (mild persecution) of 160 cases. Percentage comparisons between different types of crime or high crime by 38,5\% for Curas in Kecamatan Lampasi Tigo Nagari and the lowest at $6,1 \%$ for the Curanmor occurred in the Kecamatan Luhak. Vulnerability crime in Jurisdiction of Police Resort (the police) of Payakumbuh occurred as the highest in Kecamatan Payakumbuh Barat at 49 times per population and the lowest in Kecamatan Lampasi Tigo Nagari 4 times unity of the population.
\end{abstract}

Keywords: Crime, Map, Vulnerability

\footnotetext{
${ }^{1}$ Mahasiswa Program Studi Pendidikan Geografi untuk Wisuda September 2017

${ }^{2}$ Dosen Jurusan Geografi Fakultas Ilmu Sosial Universitas Negeri Padang
} 


\section{PENDAHULUAN}

Kriminalitas atau tindak kejahatan bukanlah fenomena yang baru dalam kehidupan sosial. Menurut Kartono (1999:122) kriminalitas merupakan segala macam bentuk tindakan dan perbuatan yang merugikan secara ekonomis dan psikologis yang melanggar hukum yang berlaku dalam Negara Indonesia serta norma-norma sosial dan agama, jadi dapat diartikan bahwa tindak kriminalitas adalah tingkah laku yang melanggar hukum dan norma-norma sosial sehingga masyarakat menentangnya. Kejahatan atau kriminalitas di kota-kota sudah menjadi permasalahan sosial yang membuat semua warga yang tinggal atau menetap menjadi resah karena tingkat kriminalitas yang terus meningkat setiap waktu yang juga dapat dialami pada siapa saja, kapan saja dan dimana saja. Semakin lama, kejahatan di Ibu kota dan kota-kota besar lainnya semakin meningkat bahkan di beberapa daerah dan sampai ke kota-kota kecil (Widiyanti, 1987: $5)$.

Kriminalitas memang merupakan masalah yang umum sering terjadi di keseharian masyarakat dan ada di manapun termasuk di Kota Payakumbuh.

Tindak kejahatan banyak terjadi di berbagai tempat dengan waktu dan kejadian yang berbeda, menyebabkan sulitnya menentukan daerah mana yang memiliki kerawanan kriminalitas atau rawan tindak kejahatan. Informasi tentang banyaknya tindak kejahatan sangat dibutuhkan oleh masyarakat dan penegak hukum seperti jajaran kepolisian. Informasi sangat menguntungkan dan berguna bagi masyarakat luas untuk tindakan antisipasi, khusus bagi kepolisian ini dapat membantu dalam mengambil keputusan apakah suatu daerah memerlukan pengawasan ekstra atau tidak, selain itu informasi tersebut juga dibutuhkan untuk mengetahui intensitas tindak kejahatan. Data dari kepolisian dan juga BPS Kota Payakumbuh mencatat sepanjang tahun 2014 telah terjadi tindak kriminal sebesar 1.066 kasus.

Kasus kejahatan bisa terjadi karena beberapa faktor seperti, faktor biologis (ketidaknormalan kromosom), faktor sosiologis (tidakseimbangan sosial, disorganisasi sosial), faktor psikologis (kepuasan terhadap pemenuhan kebutuhan dasar, lambatnya partum-buhan intelejensi), faktor ekonomi (pengangguran, tidakadilan ekonomi), maupun teori yang mengkombinasi keempat faktorfaktor tersebut (Susanto, 2011: V). Selain faktor di atas, faktor lain yang mempengaruhi para pelaku dalam melakukan tindak kriminalitas adalah, faktor ekonomi, kepadatan penduduk dan komposisi penduduk (akan meningkatkan daya saing, tingkat stress dan sebagainya yang berpotensi mengakibatkan seseorang untuk berbuat tindak kriminalitas, mentalitas yang labil (mempunyai jalan pikiran yang singkat tanpa memikirkan dampak yang akan terjadi), serta tingkat pengangguran yang tinggi (memicu seseorang melakukan jalan pintas untuk melakukan tindakan kriminal) (http://biantri.blogspot.com).

Tindak kriminalitas bisa berpengaruh terhadap keamanan masyarakat serta mengancam ketenangan lahir dan batinnya. Apabila masyarakat merasa terancam keamanannya maka besar kemungkinan pengaruhnya terhadap kesejahteraan dan ketentraman masyarakat tersebut. Dalam melakukan studi kejahatan, ada beberapa cara atau metode yang dapat dikembangkan. Salah satunya dengan 
mengggunakan data statistik kriminal, dimana gejala-gejala kejahatan pada suatu wilayah dapat dipelajari dalam angka-angka. Distribusi data kriminal secara spasial dengan menggunkan peta kriminalitas akan sangat membantu dalam langkah evaluasi keadaan kriminalitas di suatu wilayah hukum.

Nurdiati (2011: 2) mengemukakan bahwa pemetaan tindak kejahatan menjadi sangat penting karena dengan adanya pemetaan secara elektronis, pola penyebaran suatu tindak kejahatan dapat diketahui. Selain itu, alokasi sumberdaya yang terbatas juga dapat dilakukan secara efektif dan efisien

(Harris, 2003). Polwil (Kepolisian Wilayah) dalam Nurdiati (2011: 2) menyatakan bahwa pemetaan tindak kejahatan sangat bermanfaat, salah satunya adalah mengetahui pola tindak kejahatan di suatu daerah dan pengambilan keputusan serta kebijakan bagi para aparat kepolisian untuk menjalankan tugasnya dengan baik dalam mengurangi tindak kejahatan di suatu daerah.

Sistem Informasi Geografi (SIG) adalah sebuah alat analitis dengan manfaat utama untuk mengindentifikasi relasi spasial dari masing-masing karakteristik yang digambarkan pada peta (ESRI, 1995). Sistem Informasi Geografi dapat digunakan sebagai salah satu alat bantu dalam melakukan analisis dan pengambilan keputusan. Pada bidang kepolisian, praktis aplikasi SIG bisa saja bertindak sebagai pengganti petapeta dinding beserta pin-pin yang tertempel di atasnya. Dengan aplikasi SIG peta-peta dinding akan digantikan dengan layer-layer peta dijital (basis data spasial), pin-pin akan digantikan oleh simbol-simbol dengan variasi bentuk ukuran, dan warna yang sangat menarik, sementara catatan terkait pinpin tersebut akan digantikan oleh tooltip atau info yang dimunculkan dari tabel basis data atribut yang merekam kejadian kecelakaan atau kejahatan (beserta modus operasinya) di lapangan ( Prahasta, 2009: 24)

Bertitik tolak dari permasalahan di atas, maka penulis tertarik melakukan penelitian dengan judul

"Pemetaan Kerawanan Kriminalitas Di Wilayah Hukum Kepolisian Resort (POLRES) Kota Payakumbuh Tahun 2014“.

\section{METODE PENELITIAN}

Penelitian ini termasuk penelitian deskriptif kuantitatif yang memanfaatkan data sekunder sebagai sumber data utama. Deskriptif bertujuan untuk menggambarkan gejala atau keadaan tentang suatu variabel apa adanya di lapangan (Khairani \& Nawi, 2009:5). Disebut kuantitatif karena penelitian dilakukan dengan mengumpulkan data yang berupa angka kemudian diolah dan dianalisis untuk mendapatkan informasi ilmiah dibalik angka-angka tersebut. Menurut Neuman dalam Martono (2010:20) metode ini juga disebut dengan analisis data sekunder karena memanfaatkan data yang sudah tersedia di lembaga pemerintahan yang lain.

Tempat penelitian dilakukan di Wilayah Hukum Kepolisian Resort (Polres) Kota Payakumbuh Provinsi Sumatera Barat dan kegiatan penelitian dilaksanakan pada bulan Januari sampai dengan April tahun 2015.

Populasi pada penelitian ini adalah seluruh jenis tindak kriminalitas yang ada di Wilayah Hukum Kepolisian Resort Kota Payakumbuh, sedangkan sampel 
penelitiannya beberapa dari jenis tindak kriminalitas yaitu: Curas (pencurian dengan kekerasan), Curat (pencurian dengan pemberatan), Curanmor (pencurian kendaraan bermotor), Anirat (penganiayaan berat), dan Aniring (penganiayaan ringan). Penelitian ini memakai teknik Quota sampling yang metode pengambilan sampelnya mempunyai ciri-ciri tertentu sesuai dengan jumlah atau kuota yang diinginkan. Sampel dapat distratifikasi sedemikian rupa berdasarkan ciri-cirinya, kemudian dipillih sampel yang dianggap representasif sesuai dengan kuota dalam strata tersebut.

Teknik analisis data yang digunakan peneliti dalam penelitian ini adalah pengukuran kerawanan kriminalitas menggunakan rumus Crime Rite (CR):

$\mathrm{CR}=\frac{\text { Jumlah Kejahatan }}{\text { Jumlah Penduduk }} \times 100.000$

Mengukur perbandingan persentase antara berbagai jenis kejahatan atau tindak kriminalitas menggunakan rumus Crime Patten (CP):

$\mathrm{CP}=\frac{\text { Jmlh Setiap Kasus }}{\text { Jmlh Seluruh Kejahatan Kekerasan }} \times 100 \%$

Dan Pemetaan kerawanan

kriminalitas berdasarkan jenis tindak kriminalitasnya dengan teknik overlay.

\section{HASIL PENELITIAN DAN PEMBAHASAN}

Berdasarkan hasil kerja lapangan dan hasil penelitian dikemukakan sebelumnya, maka pembahasan hasil penelitian ini dibahas lebih lanjut dalam uraian berikut ini:

Tindak Kriminalitas Yang Terjadi Di Wilayah Hukum Kepolisian Resort Kota Payakumbuh, Jenis tindak kriminalitas yang terjadi di Wilayah Hukum Kepolisian Resort
Kota Payakumbuh adalah Curas (pencurian dengan kekerasan), Curat (pencurian dengan pemberatan), Curanmor (pencurian kendaraan bermotor), Anirat (penganiayan berat) dan Aniring (penganiaya ringan) dengan jumlah kasus yang beragam. Rata-rata jenis kriminalitas terbesar terjadi di Kecamatan Payakumbuh Barat. Hal tersebut sangat mempengaruhi keamanan masyarakat karena akan menimbulkan kerugian materil maupun jiwa.

Kerawanan Kriminal dan Persentase Perbandingan Antara Berbagai Jenis Kejahatan Atau Tindak Kriminalitas Di Wilayah Hukum Kepolisian Resort Kota Payakumbuh Tahun 2014

a. Kerawanan

Kerawanan kriminal merupakan keadaan yang menimbulkan gangguan atau bahaya yang bersifat kriminal serta dapat dikenai hukum pidana. Berdasarkan hasil pengolahan data penelitian, kerawanan kriminalitas di Wilayah Hukum Kepolisian Resort (POLRES) Kota Payakumbuh terbesar terjadi di Kecamatan Payakumbuh Barat dengan jumlah penduduk sebanyak 48.537 Jiwa, terjadi 49 kali perbuatan tindak krimalitas untuk setiap 10.000 Jiwa penduduknya. Sementara untuk tindak kriminalitas terkecil terjadi di Kecamatan Lampasi Tigo Nagari dengan jumlah penduduk 9.122 Jiwa, terjadi 4 kali perbuatan tindak kriminalitas untuk setiap 1.000 Jiwa penduduknya.

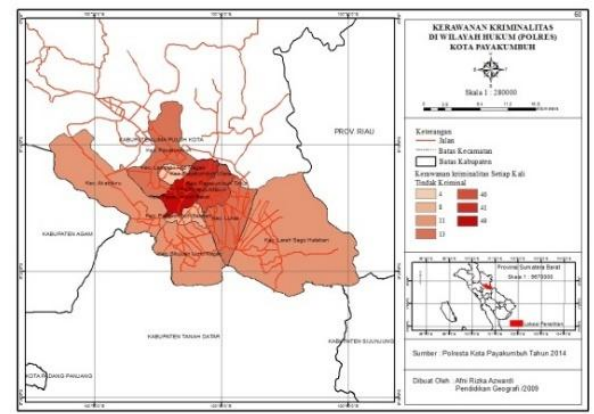




\section{Gambar 1. Tingkat kriminalitas}

Kerawanan kriminalitas ini dapat dilihat dengan cara analisis statistik kejahatan, yaitu Crime Rate (CR) adalah angka yang menunjukan pada kerawanan suatu jenis kejahatan pada suatu daerah (kota) dalam waktu tertentu (Alam, 2010:24). Uraian di atas menjelaskan bahwa kerawanan kriminalitas adalah keadaan yang menimbulkan gangguan atau bahaya yang bersifat kriminal serta dapat dikenai hukum pidana. Hal ini dipengaruhi oleh jumlah kasus tindakan kriminalitas dan jumlah penduduk. Semakin tinggi jumlah kriminal dan semakin besar jumlah penduduk maka kerawanan semakin tinggi. Begitu juga sebaliknya semakin rendah jumlah kasus tindakan kriminalitas dan semakin kecil jumlah penduduk maka kerawanan akan semakin rendah.

b. Persentase Perbandingan Antara Berbagai Jenis Kejahatan atau Tindak Kriminal.

jenis $\begin{array}{rrr}\text { Perbandingan untuk berbagai } \\ \text { kejahatan atau tindak }\end{array}$ kriminalitas dengan jenis kejahatan atau tindak kriminalitas lainnya bisa dilihat dengan cara mengukurnya menggunakan rumus Crime Patten (CP). Berdasarkan hasil pengolahan data penelitian untuk perbandingan persentase tiap jenis kejahatan atau tindak kriminalitas di Wilayah Hukum Kepolisian Resort (POLRES) Kota Payakumbuh bervariasi. Persentase tertinggi terdapat pada tindak kriminalitas Curat yaitu sebesar 38,5\% dan persentase terendah terdapat pada tindak kriminalitas Curanmor yaitu sebesar $6,1 \%$.

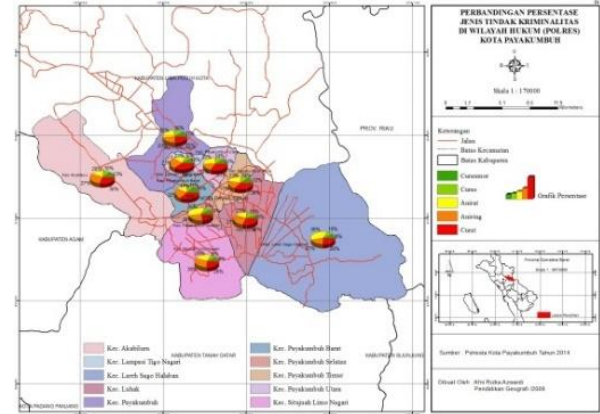

Gambar 2. Persentase kriminalitas

\section{KESIMPULAN DAN SARAN}

Dari hasil penelitian di lapangan mengenai tingkat kerawanan kriminalitas di Kota Payakumbuh tahun 2014 dapat disimpulkan sebagai berikut:

1. Jenis tindak kriminalitas diteliti meliputi jenis kriminalitas yaitu, Curas (pencurian dengan kekerasan) sebanyak 88 kasus, Curat (pencurian dengan pemberatan) sebanyak 242 kasus, Curanmor (pencurian sepeda bermotor) sebanyak 87 kasus, Anirat (penganiayaan berat) sebanyak 176 kasus, dan Aniring (penganiayaan ringan) sebanyak 160 kasus. Persentase perbandingan antara berbagai jenis kejahatan atau tindak kriminalitas tertinggi sebesar 38,5\% untuk Curat di Kecamatan Lampasi Tigo Nagari dan yang paling rendah sebesar $6,1 \%$ untuk Curanmor terjadi di Kecamatan.

2. Kerawanan tindak kriminalitas terbesar di wilayah hukum Kota Payakumbuh terjadi di Kecamatan Payakumbuh Barat yaitu sebesar 49 kali per satuan penduduknya dan terendah di Kecamatan Lampasi Tigo Nagari sebesar 4 kali per satuan penduduknya dan menyajikan ke dalam bentuk peta.

Adapun saran terkait adalah:

1. Disarankan kepada masyarakat untuk lebih teliti dan waspada 
dalam menjaga keamanan lingkungan sekitar sehingga dapat mengurangi terjadinya tindak kriminal.

2. Diharapkan kepada masyarakat untuk menggalakkan kembali bentuk perlindungan sosial yang selama ini sudah ada, misalnya Siskamling (Sistem Keamanan Lingkungan) dengan lebih efektif. Jika kontrol masyarakat lebih kuat maka hal ini akan dapat mengurangi angka tindak kriminalitas.

3. Disarankan kepada pihak kepolisian untuk lebih memperketat pengawasan di daerah yang rawan terjadi tindak kriminalitas, guna untuk mengantisipasi terjadinya tindak kriminalitas yang lebih tinggi lagi

4. Diharapkan masyarakat dan pihak kepolisian mampu berkoordinasi dan bekerja sama dengan baik dalam usaha menjaga keamanan masyarakat dan lingkungan setempat.
DAFTAR PUSTAKA

Badan Pusat Statistik. 2013. Payakumbuh Dalam Angka $2013 . \quad$ Payakumbuh: BAPPEDA dan BPS Payakumbuh. . 2014. Payakumbuh Dalam Angka 2014. Payakumbuh: BAPPEDA dan BPS Payakumbuh.

Martono, Nanang. 2011. Metode Penelitian Kuantitatif (Analisis isi dan Analisis Data Sekunder). Jakarta: PT Rajagrafindo Persada.

Nawi, Marnis dan Khairani. 2009. Panduan Menyusun Proposal Penelitian Dengan Mudah. Padang: Yajikha Padang.

Nurdiati, Sri dkk. 2007. Pengembangan Sistem Informasi Geografi Tindak Kejahatan Multimedia Berbasis Web. (Jurnal). IPB

Prahasta, Eddy. 2009. Sistem Informasi Geografis. Bandung: Informatika.

Susanto, I.S. 2011. Kriminologi. Yogyakarta: Genta Publising.

Widiyanti, Ninik dan Yulius Waskita. 1987. Kejahatan Dalam Masyarakat dan Pencegahannya. Jakarta: Bina Aksara. 